\title{
TRENDS AND ISSUES IN FINANCING AGRICULTURE: A GLOBAL PERSPECTIVE AND LOOK AT TURKISH CASE
}

\author{
Celal TAŞÇI*
}

\begin{abstract}
Recent statistics reveal that by 2050 a minimum $70 \%$ increase in agricultural production is to be achieved to feed the steadily growing world population. Climate change, frequent natural disasters, soil degradation and urbanisation reduce cultivable land areas and result in imbalance between supply and demand of food commodities. As a consequence, higher agricultural commodity prices and food shortages require more support to increase food production and to combat poverty. Lack of access to finance is a key impediment for the majority of farmers in improving the efficiency of their productions and adopting better technologies.

With reference to agricultural financing field, we overviewed historical trends, issues, financing methods and policy preferences within a global perspective and a framework for Turkey. Based on the secondary data, utilizing time-series illustrative analysis, our research question focused on the adequacy and efficiency of formal credit resources allocated to agricultural sector in Turkey. We revealed that during the rewiev period, the relative size of formal credit resources allocated to agricultural area decreased gradually; recent inflantionary trend in Turkey is triggered by high food prices and; new adjustment policy measures that include selective credit policy tools are required.
\end{abstract}

Keywords: Agricultural sector, agricultural finance, financing methods.

Jel Codes: Q, Q1, Q14

\section{TARIMSAL FINANSMANDA TRENDLER VE SORUNLAR: GLOBAL BİR BAKIŞ VE TÜRKIYYE UYGULAMASI}

\section{Öz}

Yakın tarihli istatistikler, devamlı büyüyen Dünya nüfusunu beslemek için 2050 yılına kadar tarımsal üretimde en az 70\% büyüme gerektiğini göstermektedir. İklim değişikliği, sıkça yaşanan doğal felaketler,

Assist. Prof. Dr., Trakya University, School of Applied Sciences, celaltasci@trakya.edu.tr 
toprak dejenerasyonu ve şehirleşme ekilebilir alanları azaltarak gıda maddelerinde arz talep dengesizliğine neden olmaktadır. Yükselen tarımsal madde fiyatları ve gıda kıtlıkları sonuçunda, tarımsal üretimi arttırmak ve fakirlikle mücadele için daha fazla desteğe ihtiyaç duyulmaktadır. Finansman temininde yaşanan engeller tarımsal işletmelerin çoğunluğunu etkileyerek tarımsal verimin arttırılması ve ileri teknolojilerin kullanılmasını önlemektedir.

Çalışmamızda tarımsal finansman alanındaki tarihsel trendler, metodlar ve uygulama politikaları global perspektif ve Türkiye kapsamında incelama konusu yapılmıştır. Araştırmamız ikinci kaynaktan sağlanan zaman serisi verilerine dayalı grafiksel analiz kapsamında Türkiye’de bankacılık sektörünce tarımsal sektöre tahsis edilen kredi kaynaklarının yeterli ve etkin olup olmadığını ortaya koymayı amaçlamaktadır. İnceleme döneminde tarım sektörüne tahsis edilen tarımsal kredilerin nisbi büyüklüğünün tedricen düştüğü anlaşılmıştır. Türkiye'de yakın geçmişte oluşan enflasyon trendinin gıda fiyatlarına bağlı olan yükselişi, selektif kredi uygulamaları kapsamında oluşturulacak düzeltici bir kredi politikasına ihtiyaç göstermektedir.

Anahtar Kelimeler: Tarımsal sektör, tarımsal finansman, finansman metodları

Jel Kodları: Q, Q1, Q14

\section{Introduction}

As a subset of rural finance, agricultural finance defines financial services for agricultural production, processing and marketing, such as loans, leasing, and insurance. Recently, the concept of agricultural value chain finance was introduced to emphasise the vertical dimension of agricultural finance. Rural finance, which is a broader concept, includes rural financial services such as loans, savings, payments and money transfer services and risk management. Microfinance is another related concept with agricultural finance which partly overlaps with rural finance. According to Christen and Pearce (2005), microfinance refers to the provision of financial services to small farmers and poor rural households for agricultural production, marketing and processing (Hollinger, 2011).

About half of the world's population that comprise of more than 3 billion people maintain life in rural areas. Almost 2.5 billion of these rural people earn a living for the family from agriculture. Approximately three-quarters of the world's agricultural value added is generated in developing countries, and in many of these, the agriculture sector contributes as much as 30 percent to gross domestic product (GDP). Agriculture also provide an important shelter against global economic and financial turmoil, often more effectively than other sectors. It is witnessed that the agriculture sector has demonstrated astonishing resilience during global economic turmoil (FAO, 2013).

Agriculture potential is remarkable to alleviate poverty in a way that on average, the contribution of agriculture to raising the incomes of the poorest is estimated to be at least 2.5 times higher than that of non-agriculture sectors in developing countries (UNEP, 2011). Agriculture also contributes about $40 \%$ of worldwide employment. Studies show that a $100 \%$ food production 
increase will be required in developing countries to feed the 2050 population. Emphasizing the correlation between increasing yields and return on labour with poverty, Irz et al. (2001) estimated that for every 10 per cent increase in farm yields, there was a 7 per cent reduction in poverty in Africa and more than a 5 per cent poverty reduction effect for Asia. Owing to the urban bias of many national government policies (Lipton 1977), allocated financial resources remained limited and required investments decreased for developing a thriving agriculture sector. Government expenditures on agriculture in developing countries also recorded a downward trend after 1980s (UN-DESA Policy Brief 8, October, 2008). Lack of access to finance is a key obstacle to farmers in improving the efficiency of their productions and implementing innovative Technologies (IFC,2014). There is now broad consensus that the issue of agricultural finance require more support to increase food production and to combat poverty.

Agriculture is of key importance to Turkey in terms of social and economic ground. In order to create a sustainable, competitive and organised agricultural sector Turkey requires to utilise its resources efficiently and effectively. For developing such an agricultural sector, farmers of all sizes should have better access to finance. In this context, the commercial banks are to be motivated to have a leading role, as agriculture is a profitable business segment if done professionally and offers a huge potential for bank lending. Almost all companies operating in the sector are in need of finance in line with the agricultural production cycles. Financing small-sized enterprises is of utmost importance for future development of the sector. As is demonstrated in the following sections, the data shows that following the policy changes that phase out distortions, allocated bank credits to the sector remained poor. To develop adjustment policies by the government can help combat rising inflation that generates from high food prices, as well as increase employment level and total income.

The study investigates agricultural credit resources allocated by banking sector in Turkey in the light of global trends and issues. The broad objective of the study is to better understand credit mechanisms implemented by financial institutions; to elaborate on agricultural aggregate credit resources interacting with main indicators and policy issues and; to address sectoral policy issues with the aim of contributing to the theory that reform policy implementations should be supported by adjustment policy programs to improve market imbalances.

The review period for the assessment begins in 2001, and continues up to 2014. We used graphical illustrations utilizing time series(Trend) analysis method that is a technique implemented mostly to analyze data received from several financial statements over a series of years. According to Charles and Patricia (1983:99), by looking at the trend developed through the time series analysis of financial data, one can see whether the performance of a company is falling, rising or is relatively constant. The data for calculating the graphical trends stem from two sources. Formal credit figures are calculated based on the data taken from consolidated banking sector balance sheets published by the Banks Association of Turkey(TBB) while all others come from the Turkish Istatistical Institute(TUIK). Due to lack of data in informal credit resources our studies and evaluations will be limited to TBB's resources. 


\section{Literature Review}

Cervantes-Godoy and Dewbre (2010) assessed agricultural issues in many aspect including access to output and input markets accommodated by a good transportation, marketing and processing infrastructure; non-discriminatory tax and trade policy; high rates of investment in agricultural research and extension; a system of ownership rights; employment creating nonagricultural growth; well functioning institutions and good governance are necessary conditions for agricultural and economic growth.

Levine (1997) indicated that economists have held different views about the importance of the financial system for economic growth. Some believed the financial sector merely responds to economic development, adjusting to changing demands from the real sector. Others believed that financial systems play a crucial role in alleviating market frictions and hence influence savings rates, investment decisions, technological innovation, and long-run growth rates.

Binswanger et al, ( 1993) made a one comprehensive studied investment decisions of government, financial institutions, and farmers and the effects on agricultural investments and output in India. The study covered the 1960s and 1970s, a period when India aggressively expanded its financial system into rural areas. The authors found that the availability of credit was more important than subsidized interest rates, and the expansion of banking had a larger impact on output through expanding fertilizer use than through increased investments. Bank expansion was greatly aided by government road investments and reduced transaction costs for banks and farmers.

The authors of the World Development Report (World Bank, 2007) argued that financial constraints are more pervasive in agriculture than in other sectors. Securing broader access to financial services of credit, savings, insurance, and transfer services for remittances and decreasing exposure to uninsured risks requires financial instruments that improve the productivity, profitability, and sustainability of smallholders. The report recognized the challenges and argued for financial innovations that put smallholders on a ladder of ascending financial market access flowing up from microfinance institutions to commercial lenders.

The author of the Joint Discussion Paper (World Bank, 2011) indicated that Financial services may provide the poor with considerable benefits to manage their money. But large size creditworthy farmers that employ large amount of inputs can be more important for achieving higher aggregate food production, if provided access to credit. However, subsistence farmers that have access to land, inputs, and markets, may realize relatively large benefits from small loans. Improved access to large loans with attractive terms and conditions will, therefore, be more important for commercial food production than for livelihoods and poverty alleviation. The experience on microloans reveals highly successful results in smoothing household consumption, improving food security, and meeting household emergencies and education expenses. The challenge is to develop sustainable financial systems that meet demand of both small and large scale farmers. 
Swinnen and Gow (1997) assessed the problems of agricultural finance in Central and Eastern European countries during the present transitionary period and the role of government in solving the problems. They examined the impacts of asymmetric information, adverse selection, moral hazard, credit rationing, the choice of optimal debt instrument and initial investment issues in well developed market economies.

Bayaner and Bor (2006) analyzed the impacts of Direct Income Support (DIS) system in fostering agricultural income and growth. They suggested that DIS can also have some undesirable impacts on agricultural and rural communities as related policy implementation in one country does not guarantee success in other countries because of structural differences. The impacts of DIS on Turkish agricultural sector are estimated that production and agricultural resulting in social instability in the urban areas during the medium or long run.

Erdem and Nazlığlu (2008) analized agricultural subsidy policies in Turkey and assessed the impacts of those policies on income distribution.

Tanrıvermis and Bayaner (2006) investigated formal and informal agricultural credit system in Turkey. They indicated that formal credit system in the form of banks and Agricultural Credit ooperatives (ACCs) have an important role in financing small scale farms in Turkey. They found ACCs efforts insufficient to modernize agriculture mainly due to arising problems in the areas of social capital, moral hazard, and asymmetric information.

Mıhcı and Mollavelioğlu (2011) assessed the efficiency of the Turkish agricultural sector with a comparative analysis using the data from 23 OECD countries by utilizing data envelopment analysis (DEA) method. They found that a limited number of OECD countries like Belgium, Denmark, the Netherlands and Slovakia achieved production efficiency in agricultural sector. The study indicated that the production structures of the said countries are established based on environment friendly policy allowing sustainability in their agricultural sectors. They ranked Japan, Poland and Turkey within the insufficient performance group. The study also pointed out that Turkey, as one of the worst performers, should radically change the current production structure by using labour and machinery with efficient and productive.

Bojnec (2012) analyzed the agricultural and rural capital factor markets in the three European Union candidate countries: Turkey, Croatia and the Former Yugoslav Republic of Macedonia. He suggested that agricultural and rural capital markets share similarities with the general capital market developments, but agricultural and rural capital markets are facing specific credit. Credit constraints form a limited access to finance for smallscale individual farms. Government transfers used with differing scales tend to increase over time. Remittances and donor funds have also played an important role in the agricultural and rural economy investments.

\section{Global Issues And Trends}

Rural financial services provision is to struggle several specific challenges together with those inherent in any financial intermediation. These specific challenges include seasonality, 
covariant risks and low population densities. Seasonality lead to a slow rotation of the invested capital and are reflected in the cash flows of rural entrepreneurs. On the other hand, the slower rotation of capital results in a lower profitability of agriculture and related activities. Therefore, lenders need to offer longer loan maturities and less frequent repayment instalments to match the cash flow of borrowers. Covariant risks related to weather events or price fluctuations are among the most important challenges for farmers and agricultural lenders alike. Covariant risks agricultural enterprises exposed may simultaneously affect numerous farmers and can also have a significant impact on non-agricultural enterprises in rural areas. Low population densities and poor infrastructure generate high transaction costs for rural financial service providers and for their clients reducing enterprise profitability of financial services. Consequently, total returns of rural enterprises often do not cover interest rate costs and, thereby reduce the effective demand for loans. As agriculture is a politically sensitive sector prone to government interventions, interventions in the form of lending quotas, interest rate ceilings or direct government provision of financial services tend to decrease substantially in the last few decades. However, some exceptions implemented within loan rescheduling or forgiveness and preferential lending programmes for specific target groups, derive additional uncertainties for financial institutions and tend to weaken the repayment culture. Instruments to combat with these additional challenges are fewer. Eventually, many rural financial institutions (RFIs) implement excessive credit rationing and, over-reliance on collateral to protect themselves. Due to legal and administrative impediments and cultural factors, collaterals in the form of land and other rural assets are poor protection tools for managing covariant risks. The more appropriate instruments for managing covariant risks, such as crop insurance or hedging, are rarely available. Classical microfinance techniques that offer highly standardised loan products based on small credit amounts, frequent repayments, short maturities, and collateral substitutes are difficult to apply in rural economies for larger loan amounts and longer maturities which are typical for agricultural finance. Eventually, commercially oriented financial institutions are reluctant for extending rural and agricultural credits, while less risky business opportunities are available. Because of the contribution to overall economic growth, employment and poverty reduction, governments and donors take the rural and agricultural finance as a prime concern in many developing and transition countries. Policies and instruments for fostering rural finance have evolved considerably over the past decades, reflecting fundamental changes of the underlying paradigms (Klein et al. 1999; Hoellinger, 2004).

During the 1960s and 1970s, the emphasis was on addressing market failures through massive public intervention in the form of directed and subsidised credit to accelerate the modernisation of agriculture through the adoption of Green Revolution technology packages combined with farm mechanisation and irrigation. Credit was considered as an input for agriculture production and specific institutions such as agricultural development banks. Cooperatives were established to make cheap credit widely available to farmers. The major role of financial institutions was to channel loans at subsidised interest rates to farmers. Loan repayment was the second concern, and little attention was paid to the financial health of the lending institution. Except some developing countries from Asia, state-owned gricultural banks and credit funds yielded poor 
result in efficiency and sustainability, mainly because of poor management, political interrference and rent-seeking elites. Many institutions failed, and others required bailouts and repeated recapitalizations. A culture of nonrepayment developed among borrowers, especially when loans were viewed as coming from the government. Government failure replaced market failure because the directed credit programs generally failed to resolve the screening, incentive, and enforcement problems in rural lending. Consequently, low level interest rates and high loan losses further undermined the solvency and profitability of financial institutions and periodic capital injections were required to keep the lending institutions alive (Hoff and Stiglitz 1990; Hollinger, 2011).

Despite the large amounts of public funds invested, outreach to small farms and landless households often remained limited. Agricultural banks pursued a selective lending policy and prefered to finance medium and large farmers with sufficient collateral. Eventually, the majority of rural households still did not have access to credit and any other financial services in many countries (Meyer and Nagarajan, 2005; FAO/GTZ, 1998).

During the 1980s, in line with the structural adjustment programmes and fiscal austerity, agricultural credit policies were to change resulting sharp decline in bulky fund resources for agricultural banks and credit projects. Being Latin America and Africa in the first place, many countries liberalised their financial markets phasing agricultural development banks and agricultural credits out of financial markets. Meanwhile, microfinance gained popularity amongst donors and governments. With a appropriate institutional arrangements and financing technologies, pioneering financial institutions such as Grameen Bank, Banco Sol, Bank Rakyat Indonesia and others started to serve to unbankable poor households in a cost-covering way. The lending institutions were able to become financially sustainable anymore. By the late 1980s, the accumulated criticisms of the old paradigm combined with the emerging success of microfinance led to a rejection of the directed credit approach and the emergence of a new financial systems paradigm. The new paradigm trend appeared focused on the development of efficient and inclusive financial systems and markets (Yaron, Benjamin, and Piprek, 1997; FAO/GTZ, 1998; World Bank, 2003; and IFAD, 2010).

The new approach was formally incorporated in the policies of the international agencies. A World Bank report briefly summarized the specific documents within the rural finance institutions that demonstrate adoption of the new paradigm (World Bank, 2003). The financial systems approach gave efficient financial institutions priority for economic development and poverty reduction. The target was to develop stable, efficient and inclusive financial systems as a development objective. According to this approach, governments should put an end to providing financial services directly or intervening in financial markets. Lending quotas, interest rate ceilings or subsidised funding to priority sectors should be avoided as they would distort resource allocation and crowd out private financial institutions. The governments' main role was to built up a conducive framework conditions and an enabling environment for the development of competitive and transparent financial markets and effective financial intermediation. A strong legal and regulatory framework for different types of financial institutions was also required to create an effective supervision system. Another important area for public sector investments is to 
develop transport and communication infrastructure to reduce transaction costs and enhance the profitability in rural areas. Based on new approach, subsidies to financial institutions should be limited to institutional strengthening and capacity building, with a view to enhancing outreach, financial sustainability and poverty reduction impact. Subsidised funds for on-lending might only be justified for a limited time period to compensate financial institutions for the higher initial costs and risks of launching financial innovations. Interest rates for clients should not be subsidised. According to the Financial Systems Approach, victims of wars or natural disasters should be given direct grants rather than subsidised loans (Hollinger, 2011; World Bank, 2006; Klein et al., 1999; Meyer and Nagarajan, 2005).

During the 1990s, a contraction of formal financial services occured in rural areas, because of withdrawal of governments from financial sector. The private financial institutions at that time, could not meet the needs of rural areas and their interests were focusing on a few high-potential areas and non-agricultural rural activities. Commercial banks have rarely entered rural areas due to safer and more profitable business opportunities elsewhere. Microfinance has breeded mainly in non-agricultural activities of the trade and services sector. Hence, the agricultural sector continue to be heavily underserved by financial institutions in those of countries which implemented extensive financial sector reforms more than a decade ago and have followed sound macroeconomic and financial sector policies for many years.

The recent trends, experinced during the crisis period, in agricultural commodity prices have not only put agriculture back on the Global agenda but have also changed the governments' and private investors' perception of the sector. Commodity-importing countries faced deteriorating external balances, rising prices, weaker income and higher household spending. The imbalance between supply and demand of food commodities after 2006 was caused by a top end of longer-term structural trends, with support of short-term factors such as the impact of weather conditions on harvests. Structural trends and climate changes seem to be continuing in the foreseeable future. Population growth coupled with rapid urbanisation and rising incomes, especially in China, India and other emerging economies increased meat and dairy consumption and required more grain. Production growth is to struggle with declining agricultural land and water, competition from other economic sectors, desertification, soil fertility losses and climate change. Agricultural yield gaps between the most advanced countries and the majority of developing and transition countries required significant investments in rural infrastructure, support services, education and applied research over longer time periods. In view of these trends, average crop prices in real terms are expected to be $10-20 \%$ higher over the next 10 years compared to the period 1997-2006 (FAO/OECD, 2009). This marks a reversal of the long term declining trend of agricultural commodity prices. Higher agricultural commodity prices lead to higher food expenditures for consumers. Poor households with small disposable income have to tackle anymore with constant price increases on food products. The impact was most severe on the poor, who often spend 50 percent or more of their total budgets on food and fuel (World Bank, 2009). One study projected that the financial crisis would add 53 million people to the number of people living on less than $\$ 1.25$ a day and 64 million to the number of people living on 
less than $\$ 2$ a day (Chen and Ravallion, 2009). The crises threatened to reverse progress toward improving financial access because of their effects on financial institutions. If borrowers in rural and microfinance institutions(MFIs) were not able to repay their loans, MFIs might be unable to refinance their loans when due or obtain additional financing to continue their rapid growth in lending (CGAP, 2010).

The crises in developing countries derived short-term problems. First, investments in agriculture assumed by both foreign assistance and national government investment declined. As a consequence, the growth rate of agricultural productivity decreased from about 3.5 percent in the 1980 s to 1.5 percent in 2011. Second, the negative effects of climate change will likely increase food prices and may put an extra 49 million people at risk of hunger by 2030 (IFAD, 2009). Third, natural resource degradation over the next 25 years is projected to reduce global food production by as much as 12 percent, pushing world food prices as much as 30 percent higher (IFPRI/Terrafrica/GTZ, 2009).

Rising energy prices and changing energy and environmental policies over the last decade place a great emphasis on the relationship between the agriculture and energy sectors. Traditionally, agriculture uses energy both directly in the form of fuel and electricity and indirectly through use of energy-intensive inputs, such as fertilizers and pesticides. So that energy plays a large role in the production of many goods and services (Beckman et al, 2013). Energy prices became much higher and more volatile during 2001-2012 and the price of oil in that period rose 262 percent in real terms. The price increases were largely attributed to a combination of falling U.S. oil production, rising global demand, and increased speculation in financial markets (Hamilton, 2009). Farmers witnessed an upward trend in the price of energyrelated production inputs from 2001 to 2012. Oil and fuels exhibited similar price patterns in the same period. Natural gas represented approximately 70 percent of the cost in manufacturing fertilizer (Gellings and Parmenter, 2004). Although both natural gas and fertilizer prices have declined since 2008, unlike natural gas prices, fertilizer prices did not fall back to their 2001 levels depending on global demand (Schnitkey, 2011). A range of approaches have been used to assess the impact of variability in oil, biofuel and agricultural markets. Analysis conducted on the long-run relationships among oil, biofuel and agricultural commodity prices provided a means to examine price transmissions mechanism and the degree of integration between markets (Busse et al., 2010).

Risk management issues for mitigating sectoral risks are of special importance during the crisis periods. Agricultural productions permanently expose to price and production risks such as price fluctuations, weather conditions, genetics which decrease yields or lead to supply and demand imbalances. The rising trend in global markets and varying gricultural policies may also serve to trigger these risks. The increasing variability in prices and production has eventually made farmers see the importance of risk management. Global derivatives markets offer a number of risk management tools such as futures and options contracts, forward contracts and product insurance for minimizing sectoral risks. They can help the agriculture sector and also end users mitigate price risk which will be in the larger interest of the farmers. Futures contracts trading in 
commodity markets are useful to all sectors of the economy including agriculture. The agriculture sector makes a strong case for better cyclicality management through futures contracts since 1848 . So that these contracts can help to reduce the uncertainty of the market in agricultural products, they can be an important means of transferring risk to the industries which use agricultural raw materials. Other risk management instruments, forward and insurance products, are used by a smaller number of farmers (Riley and Anderson, 2009; Adanacioğlu, 2011).

Financialization of commodity trading seems to be one of the most remarkable issues in our investigation period. It refer to the increasing role of financial motives, financial markets and financial actors in commodity markets. During the the last decade, financialization of derivatives markets experienced a remarkable growth since futures contracts started to yield the same returns to investors as in equity markets (UNCTAD, 2011). It became evident that a combination of financialization and financial stress trigger a positive correlation between equity and commodity markets. In other words, financial turmoil appears to be more powerfully transmitted to agricultural prices when most trades in agricultural exchanges are made by financial investors. The influence of financial shocks on agricultural prices is likely to decrease as global financial tensions settle down. But also that, as long as agricultural derivatives markets are intensified by financial investors, it can be expected to rise again in the presence of new financial turmoil (Girardi, 2013).

It can be summarized that the recent developments experienced after peak period of the recent crisis have improved the framework conditions for investment in agriculture. The evidence is that flow of private capital into the sector and public spending for rural infrastructure started to increase. However, there are some risks connected to rapidly increasing investments in the agriculture sector, for example, over-indebtedness of borrowers and growing inequalities due to further land concentration (Hollinger, 2011).

Ttrend and issues on financing approaches reveal that there are a large number of financing models that can be classified according to repayment source or collateral into three categories: financing models which target farmer, financing models using movable assets as collateral and financing models that rely on buyers.

In financing models targeting the farmer, collateral generally requires cash flow analysis by banks in order to underwrite anticipated earnings, overall savings, and/or group guarantees. This category include models based on direct smallholder lending, indirect lending through farmer-based organizations or cooperatives, emerging farmers finance and saving account linked input finance. The direct model allows the bank to attract deposits, which lowers funding costs and facilitates more effective asset/liability management. The adventages of the indirect lending model, also known as wholesale model, are savings on costs of creditworthiness assessment and loan administration. Members guarantee each other. Emerging farm business models adres those of farmers that experience lack of working capital and lack of agronomic, technical, and financial skills to grow their businesses. Savings account in this model is directly linked to financial services that banks want to offer farmers (IFC, 2012; AGRA, 2009). 
Financing models using movable assets as collateral utilize anything from equipment to small infrastructure and commodities such as leased equipment or harvested commodities in warehouses. Models in this group consist of equipment finance, leasing, wharehouse receipt financing and collateral management agreement financing. Equipment financing model requires those of movable assets acquired as additions or supplements to available permanent assets. Lease financing only partially overcomes the typical constraints to credit financing. Leasing firms often take additional collateral from rural clients in developing countries. Warehouse receipts give the bank the security of the goods until they have been sold and the proceeds collected. The collateral management model is costly and mostly inaccessible to smallholder farmers and agricultural SMEs (IFC, 2012; USAID, 2010).

Financing models that rely on buyers are based upon an overall value chain analysis in which strong business relationships exist between farmers and buyers, and formal or informal contracts provide security to lenders. Value chain financing, nucleus farm, factoring and trade finance are major types of models. Value chain financing models involves financial flows among buyers or input suppliers, as well as flows from financial institutions into the chain, or combinations of both. The nucleus farm is generally engaged in primary production on a large farm plot, but also has other operations such as storage, processing, transportation, and market distribution for its own produce. Factoring is a powerful tool in providing financing to high-risk, ambiguous agricultural projects through which a small firm can sell its complete portfolios of receivables in order to diversify its risk to any one seller. Trade finance refers to financing international trading transactions of agricultural establishments. The bank issues guarantee for payment of goods traded on behalf of the importer. (IFC, 2012; FAO, 2004).

\section{Agricultural Finance In Turkey}

Turkey is endowed with rich natural resources. The cereal sector is the largest agricultural sector in Turkey. Almost $70 \%$ of all farms produce a type of grain. Wheat is the most important crop with $67 \%$ of total grain production, followed by barley accounting for $26 \%$ of total cereal production in 2007. Turkish prices are well above international market prices. TMO (Turkish Grain Board) may intervene the market prices significantly to stable market prices. Cereal producers are supported by direct income payments and input subsidies. Cultivating about one third of its 78 million hectares land size, Turkey achieved not only to be one of the self-sufficient in food production, but also to be the largest exporter of agricultural products in the Near East and North Africa. It ranks among the top 10 major food exporters in the world (Çakmak, 2006).

In Turkey agriculture was the main sector in 1950冈s. Of the total GDP, employment and export, $34 \%$ of GDP, $75 \%$ of employment, $77 \%$ of export was originated from agriculture. The shares have gone down gradually over time and, shifted as $8 \%$ of GDP, $26 \%$ of employment, $8 \%$ of export in 2008. Agriculture is still an important sector in the Turkish economy. Acording to IMF and CIA Worldbook, Turkey is the $8^{\text {th }}$ largest country with 68 billion $\$$ among twenty largest countries by agricultural output in 2014. Techniques adopted after 1970s have drastically 
modernized the sector with an emphasis on utilization of land, irrigation capabilities and agricultural machinery. However, agricultural sector almost recorded stagnant performance rates lower than other main sectors did during last two decades. Due to structural and resource defficiencies, the performance of agricultural sector has yielded poor results with compare to the country's potential. One of the main reasons of this consequence is the fragmentation. Nearly two-thirds of farms are smaller than 5 hectares and they tend to be fragmented at all points in the size spectrum. Turkish inheritance law is a major factor in this trend. Small scale farms mainly produce for own consumption and have insufficient operating capital that hamper input supply, technology transfer and investments. The main problem of small family farms constituting the large part of Turkish farms is lack of access to finance. Their access to agricultural supports are also restricted. Eventually, quite a number of enterprises try to get operating funds from informal credit sources with high costs and heavy conditions. The Government of Turkey has initiated a structural adjustment and stabilization program in 2000 to remove past agricultural incentives that were inefficient and costly. It comprised not only the reinstrumentation of policy and a change of policy delivery systems, but also the dismantling or fundamental reform of failing agricultural sector institutions. Fertiliser prices were linked to world market prices. Most state enterprises in agriculture have been privatised. Product and input subsidies were phased out, and replaced by direct income support (DIS) in 2001, with the technical and financial support of the World Bank. DIS system was aiming at reducing public deficits, and enhancing efficiency in crop production, marketing and transportation while, activating income generating potentials through income transfer to some groups and to re-orient income distribution. $80 \%$ of those receiving DIS are small-sized farms and, they do not intend or endeavour to earn a higher income from agriculture, nor do they intend to feed others (Burrell and Kurzweil, 2007; Tanrıvermiş and Bayaner, 2006).

The credit sytem in Turkey consist of formal and informal suppliers. The agriculture bank, other banks, and agricultural credit cooperatives (ACC) are major formal credit suppliers, while other individuals and institutions constitute informal resources. Tradesman, money brokers, commissioners, wealthy farmers, and money lenders are among the informal credit sources, all of which are short term borrowing providers with high interest rates and heavy payment conditions (Tanrıvermiş and Bayaner, 2006; Bayaner and Bor, 2006).

As a major institution from formal credit suppliers, the Bank of Agriculture (Ziraat Bankası) was distributing government based funds directly or through other channels until 2002. Following the Reform Policy Program was put into practice, the Bank reduced its agricultural loans portfolio sharply. Today, the Bank's agricultural direct lending operations have been channeled mainly to larger farms and state-owned enterprises, despite current regulation address small farm holders as target client. In this context, the Bank can also extend credits to individual farmers directly for middle or long term provided that customer meet restrective credit requirements (Oskam et al, 2004).

ACCs are one of the most important credit suppliers that actullay perform as the retail branch of the Agriculture Bank throughout the country. Of three-tier organizational structure of ACCs, the top two tiers operate as a nationwide NGO, while the base tier offer traditional cooperative services. Short term and medium term credits are typical products provided. Short term credits 
are aimed to meet the needs of small farmholders to procure seed, animal feed, chemical fertilizer, pesticides and, fuel oil. They are mostly one year fixed term credits supplied for working capital and agricultural investment needs of the cooperative members. In addition, credits for financing consumtion and insurance contracts with one-year term and credits for setting up aquaculture production and incubation facilities with three-year term are other short term credits supplied by ACCs. Medium term credits extended are those that aim to invest on fixed assets such as agricultural vehicles and equipment, fruit seedlings, apiculture, aquaculture products equipment, sericulture, and poultry farming, cattle and revenue animals for three-year term. Credit limits issued by ACCs fall into one of the following category; General Individual Credits extended up to $\$ 14.000$ with the approval of primary cooperatives, Special Individual Credits extended up to $\$ 40.000$ with the approval of regional unions and, Contracted Production Credits extended up to $\$ 40.000$ with the approval of regional unions. The members in need of higher amount of credit can be financed up to $\$ 170.000$ depending on approval of the central union. Today, ACCs include 16 regional unions, 1659 primary cooperatives, 184 service operation offices and, have 6000 employees. ACCs tasks and activities focus on meeting all sorts of agricultural input needs and credit requirements of nearly 1.1 million cooperative members employing the total assets that worth 6.5 billion TL. On the other hand, ACCs also engage in other activities related to agriculture such as production, marketing, insurance and, grocery (ACC, 2014).

Although ACCs maintain crutial role in financing agricultural sector, a recent study revealed that cooperatives are inefficient and old-fashioned organizations operating under the supervision of state bodies with heavy government bureaucracy and, lack of well trained staff. Unit cooperatives experince shortages in providing sufficient sources for credit demands and, work with costly inputs. Cooperative members in many cases default on paying the principal and installments timely expecting that the debt to cooperaives can be restructured basically due to political reasons. In addition, over employment ACC system also is to tackle with some institutional problems such as, asymmetric information, lack of social capital, and moral hazard. On the other hand, credits extended are not sufficient enough to employ modern agricultural techniques (Tanrıvermiş and Bayaner, 2006).

The regional development agencies (RDAs) may play crucial role in supporting agricultural projects in the most appropriate size, at most appropriate location, with enough finance under the most appropriate conditions. As we have no found a sufficient number of statistical figures, we are unable to assess their contribution to the area of financing agriculture. Yet, the potential of RDAs lead us to overview their background and discuss their organizational structures.

As economy was moving towards a private sector driven structure, Turkey has opted for independent sectoral regulation model. In this respect, RDAs entered into Turkish legal system with the Law of 'Establishment, Coordination and Tasks of Development Agencies with $\mathrm{Nr}$ 5449/2006. The aim of RDAs is to accelerate the regional development in line with the principles and policies anticipated in the national development plan and programmes, to ensure its sustainability, to reduce the interregional and regional gaps of development by ensuring the appropriate and active use of sources and activating the local potency. 
The establishment law of RDAs includes a provision (Article:3) stating that agencies have legal entity and are subject to private law provisions in all of their actions which are not regulated in the law. But it is not clarified that if they carrry pirvate or public entity status. One of the important factors for the success of RDAs is financial issues. The existence of resources determines the efficiency of RDAs in achieving their missions. Legality and authority come to the next which indicate that in order to enhance the effectiveness of RDAs, they need to be supported bottomup in local base and top-down by central governments. Another issue that affect efficiencies of RDAs in Turkey is to adopt the decentralization tradition despite that RDAs require more comprehensive and more unique effective regional policy tools and actions rather than centrally oriented supports (Toktaş, Sevinç and Bozkurt, 2013).

\section{Findings}

The dataset used for the calculations of the following conclusions is obtained from the regular official statistical reports of TUIK and TBB. As a proxy for our assesments we employ changes, maximum and minumum values of time series data. Our Proxy for analyzing agricultural formal credit figures and agricultural GDP figures we employed trend index used on figure 3 and on figure 4. The trend index for each item is calculated by taking the year 1999 as a base year. The base year's figure is accepted as 100 and trend indexes for the following years are calculated in relation to that of base year.

The size of arable land per person in Turkey declined from 0.38 hectare in 2000 to 0.28 hectare in 2011. Steadly decrease in size over the years is mainly due to population growth and, partly due to the decline in total cultivable area.

The consumer price index (CPI) in Turkey increased to 243 index points in 2014 from 104 index points in 2014. CPI in Turkey averaged 168 index points from 2003 until 2014, reaching an all time high of 243 index points in August of 2014.

The share of agriculture in total employment in Turkey decreased to 21.9 percent in May of 2014 from 34.9 percent in 2002. Employment in agriculture to total employment in Turkey averaged 25.9 percent from 2002 until 2014, reaching an all time high of 34.9 percent in 2002 and a record low of 21.9 percent in may of 2014 forming a steady declining pattern.

Based on Table:1, the figure:1 indicate that the GDP growth rate in Turkey at constant prices $(1998=100)$ declined from 6.8 percent in 2000 to 4 percent in 2013 whereas growth rate in agriculture decreased more from 7.1 percent in 2000 to 3.1 percent in 2013. Over the years, GDP growth rate in Turkey averaged 3.9 percent from 1999 until 2013, reaching an all time high of 9.4 percent in 2004 and a record low of -5.7 percent in 2001. Agricultural growth rate in Turkey averaged 1.8 Percent from 1999 until 2013, reaching an all time high of 8.8 percent in 2002 and a record low of -7.2 percent in 2001. Both of growth rates progressed tete a tete until 2002. Since then, growth rates for GDP stayed over the agricultural growth rates, except during the financial crisis for the years 2008 and 2009. Consequently, Turkey recorded a 10.1 percent of the Agricultural GDP to Total GDP 
ratio in 2000. The share of agricultural GDP in Turkey averaged 8.7 percent from 2000 until 2013, reaching an all time high of 10.3 percent in 2002 and a record low of 7.4 percent in 2013 . Under current circumstances the share of agriculture in GDP tend to decline over the next years.

Table I. Main Indicators Related with Agriculture

\begin{tabular}{|c|c|c|c|c|}
\hline YEARS & $\begin{array}{c}\text { GDP } \\
\text { AGRICULTURE } \\
\text { (THOUSAND TL) }\end{array}$ & $\begin{array}{c}\text { GDP } \\
\text { TOTAL } \\
\text { (THOUSAND TL) }\end{array}$ & $\begin{array}{c}\text { EMPLOYEES } \\
\text { AGRICULTURE } \\
\text { (THOUSAND) }\end{array}$ & $\begin{array}{c}\text { EMPLOYEES } \\
\text { TOTAL } \\
\text { (THOUSAND) }\end{array}$ \\
\hline $\mathbf{2 0 0 2}$ & 36.055 .787 & 350.476 .089 & 7.458 & 21.354 \\
$\mathbf{2 0 0 3}$ & 45.134 .860 & 454.780 .659 & 7.165 & 21.147 \\
$\mathbf{2 0 0 4}$ & 52.994 .026 & 559.033 .026 & 5.713 & 19.632 \\
$\mathbf{2 0 0 5}$ & 60.709 .608 & 648.931 .712 & 5.154 & 20.067 \\
$\mathbf{2 0 0 6}$ & 62.658 .502 & 758.390 .785 & 4.907 & 20.423 \\
$\mathbf{2 0 0 7}$ & 64.327 .333 & 843.178 .421 & 4.867 & 20.738 \\
$\mathbf{2 0 0 8}$ & 72.269 .626 & 950.534 .251 & 5.016 & 21.194 \\
$\mathbf{2 0 0 9}$ & 78.770 .465 & 952.558 .579 & 5.254 & 21.277 \\
$\mathbf{2 0 1 0}$ & 92.732 .631 & 1.098 .799 .348 & 5.683 & 22.594 \\
$\mathbf{2 0 1 1}$ & 103.628 .154 & 1.297 .713 .210 & 6.143 & 24.110 \\
$\mathbf{2 0 1 2}$ & 111.682 .488 & 1.416 .798 .490 & 5.686 & 24.766 \\
$\mathbf{2 0 1 3}$ & 115.941 .507 & 1.561 .510 .015 & 5.507 & 25.262 \\
\hline
\end{tabular}

Source: Tuik (NACE Rev2, 1998=100)

Figure I. Agriculture and GDP Growth Rates in Constant Prices

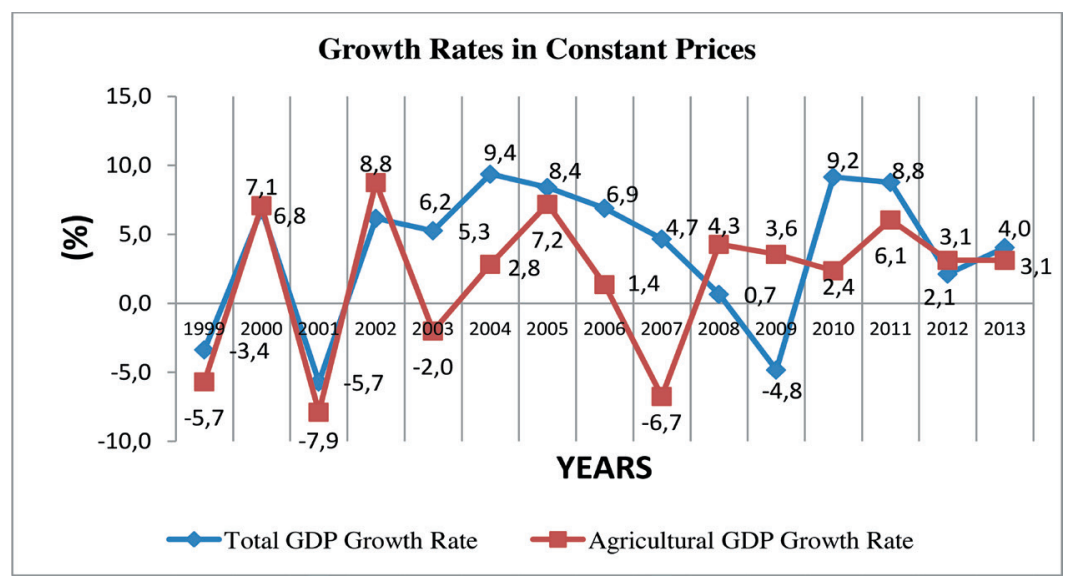

Source: Depicted and calculated by the author based on The TUIK Data 
Table: 2 reveals that Turkey recorded a 3 percent of the agricultural credits to Total credits ratio in 2013 declining from 7 percent in 2002. The relative size of agricultural credits to total credit volume in Turkey averaged 4 percent from 2002 until 2013, reaching an all time high of 7 percent in 2002 and maintaining a continous record low of 3 percent between 2006 and 2013, except 2012. Under current circumstances the share of agricultural credits relative to total credit volume tend to keep the same size over the next years. As a policy tool of supporting agricultural sector, DIS illustrates a steady decrease over the years. DIS to agricultural credit volume declined to 20 percent in 2013 from 75 percent in 2002 whereas DIS to total credit volume in Turkey recorded a 1 percent value in 2013 decreasing from 3 percent in 2002.

Table 2. Financial Indicators on Agricultural Finance

\begin{tabular}{|c|c|c|c|c|c|}
\hline YEARS & $\begin{array}{c}(1) \\
\text { TOTAL } \\
\text { AGRICULTURAL } \\
\text { CREDIT VOLUME(*) }\end{array}$ & $\begin{array}{c}(2) \\
\text { TOTAL CREDIT } \\
\text { VOLUME IN } \\
\text { TURKEY }\end{array}$ & $\begin{array}{c}(3) \\
\text { TOTAL } \\
\text { DIS }\left(^{* *} \text { IN }\right. \\
\text { THE SECTOR(*) }\end{array}$ & $(1) /(2)$ & $(3) /(1)$ \\
\hline 2002 & 2.440 & 52.631 & 1.821 & 0,07 & 0,75 \\
2003 & 3.216 & 69.002 & 2.623 & 0,05 & 0,82 \\
2004 & 3.847 & 102.482 & 2.872 & 0,05 & 0,75 \\
2005 & 5.277 & 152.295 & 3.423 & 0,04 & 0,65 \\
2006 & 5.979 & 217.309 & 4.387 & 0,03 & 0,73 \\
2007 & 7.481 & 278.998 & 4.803 & 0,03 & 0,64 \\
2008 & 9.834 & 363.861 & 4.436 & 0,03 & 0,45 \\
2009 & 11.490 & 379.405 & 3.538 & 0,03 & 0,31 \\
2010 & 17.727 & 506.994 & 4.351 & 0,03 & 0,25 \\
2011 & 24.528 & 660.884 & 4.960 & 0,03 & 0,20 \\
2012 & 24.868 & 764.197 & 5.094 & 0,04 & 0,20 \\
2013 & 26.552 & 1.009 .763 & 5.403 & 0,03 & 0,20 \\
\hline
\end{tabular}

(*): IN MILLION TURKISH LIRA - $\left(^{* *)}\right.$ : DIRECT INCOME SUPPORT

Source: Calculated by the author based on TUIK data.

Figure 2. Trends on Growth Rates in Agricultural and Total Credit Volumes

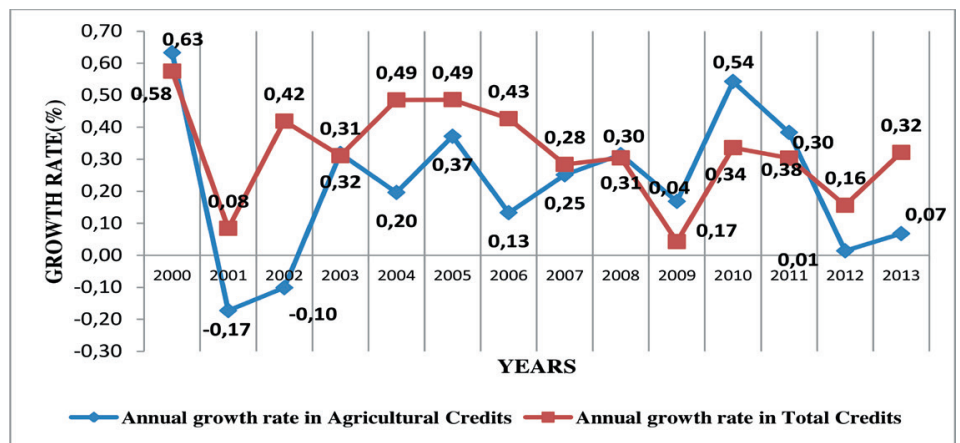

Source: Depicted and calculated by the author based on The Banks Association data 
Figure: 2 Illustrate that the agricultural credits growth rate in Turkey declined from 63 percent in 2000 to 7 percent in 2013 whereas growth rate in total credit volume in Turkey decreased from 58 percent in 2000 to 32 percent in 2013. Over the years, growth rate in total credit volume in Turkey averaged 32 Percent from 2000 until 2013, reaching an all time high of 58 percent in 2000 and a record low of 4 Percent in 2009. Agricultural credit volume growth rate in Turkey averaged 22 Percent from 2000 until 2013, reaching an all time high of 63 Percent in 2000 and a record low of 1 Percent in 2012. Beyond the recovery period of recent financial crisis, total credit volume growth rates in Turkey formed an uptrend over the trend line depicted for agricultural credit volumes growth rates. The same trend formation tend to continue after 2011.

Figure 3. Trend Analysis For Credit to Agriculture Vs Credit to All Other Sectors

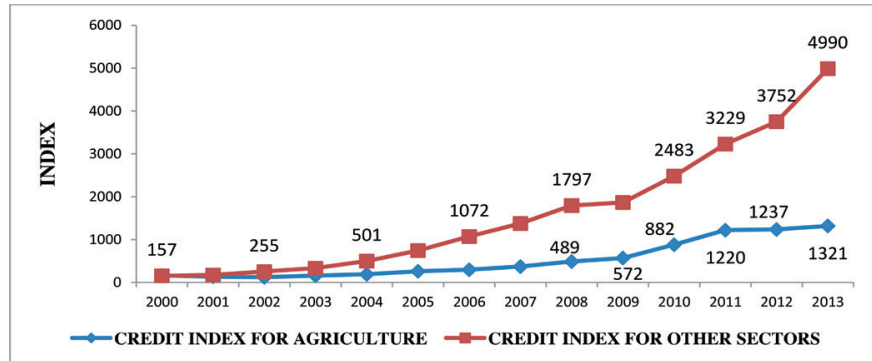

Source: Depicted and calculated by the author based on The Banks Association data

The figure: 3 indicate that the trend index of agricultural credits in Turkey increased from 100 in 1999 to 1321 in 2013 whereas the trend indeex of credit volume to all other sectors boosted from 100 in 2000 to 4650 in 2013 recording 3.5 times greater increases than agricultural credit volume. The credit resources allocated to agriculture in Turkey could not maintain its relative size since the year of 2000 and tend to shrink over the following years.

Figure 4. Analysis For Agricultural Credits Vs Agricultural GDP

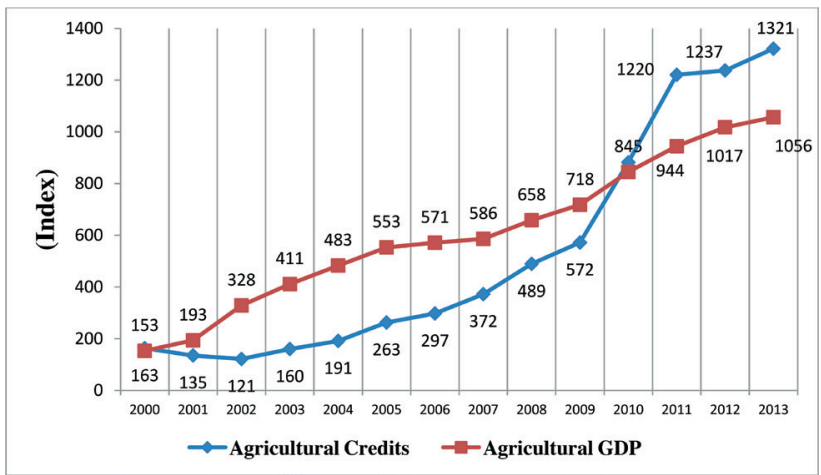

Source: Depicted and calculated by the author based on The Banks Association data 
Index analysis employed in figure: 3 is also used in figure: 4 to compare the agricultural credits volume with the Agricultural GDP volume in Turkey. The trend index on total agricultural credits increased from 100 in 1999 to 1321 in 2013 while the trend index on total agricultural GDP in Turkey increased from 100 in 1999 to 1056 in 2013. During the period from 1999 to 2010, the agricultural credits volume index kept staying under the trend line of agricultural GDP, thereafter it increased in size forming an uptrend position over the agricultural GDP index line.

Food inflation in Turkey started to increase in 2014. It reached to 14.44 percent in August from 12.56 percent in July. Food inflation rate in Turkey averaged 9.13 percent from 2004 until 2014, reaching an all time high of 17.08 percent in October of 2010 and a record low of 1.76 percent in October of 2011.

\section{Conclusions}

Investigated main indicators reveal that the share of agriculture in Turkey continues to shrink. This is relevant to previous studies assessing that a declining share for agriculture in national employment and GDP is an inevitable consequence of economic progress (CervantesGodoy and Dewbre, 2010; Byerlee, de Janvry and Sadoulet, 2009; Timmer, 1988; Cervantes and Brooks, 2009).

Agricultural policy reform that begun in 2000 phased out all distortions such as state subsidies to establish a basis for market conditions for rural development. As the rewiev period figures suggest, the level of governmental supports granted to agriculture since 2000 is lower relative to that of the 1990s. Nevertheless, our study reveals that relative size of formal credit resources for agriculture with compare to those of credit resources allocated to all other sectors also decreased gradually during the rewiev period.

Due to climate changes, natural disasters, droughts and financial crises, global supply of agricultural outputs tend to decline while resulting in price fluctuations and increases. As many other countries, Turkey was heavily affected by those of global events. Emprical studies indicate that Turkish agriculture is sensitive to drought and climate change. Under the effects of drought, national and regional production are negatively affected in the range of minus $4.5 \%$ to minus $15.3 \%$. Under climate change, crop yield changes are negatively affected beteween 3.8\% and 10.1\% ( McCarl and Dellal, 2010; Dellal et Al, 2011). On the other hand, the share of average household expenditure on food, beverages and tobacco changes between 36 percent and 56 percent for Turkey (Cakmak 2003). Recently released inflation report by Central Bank of Turkish Republic assess that the elevated level of food prices has been the main factor in rising inflation. Negative supply shocks and the exchange rate pass-through caused food prices to surge significantly (CBRT, 2014). TUIK also emphasized that because of 54 food items, poverty level increase among retirees and working population.

Taking all these factors into account, Turkey's agricultural policies are to be improved in a way that in order to recover the supply imbalances, essential shifts in production for those of 
foods that trigger market prices are to be provided together with a selective credit policy base. For this to occur, innovative financing tools can be put into practice to transmit price reductions on poor food-consuming households. It is far from impossible as Turkey is endowed with ample land resources providing the country with a comparative advantage and potantial both to feed its population under beter living standards and to contribute more to foreign trade volume.

In addition, the problems generating from insufficient and costly financial resources mainly due to lack of financial institutions for agricultural holdings shoud be removed by building sustainable competitive rural finance institutions or by restructuring ACCs with outreach to the rural poor. As current conditions continue, sustaining efficient food supply seems to be one of the major challenges in the World. 


\section{Literature}

ACC, (2014). The web page of Central Union of Turkish Agricultural Credit Cooperatives. Available at: http://int.tarimkredi.org.tr/index.php/en.html Visited on: 14.09.2014

ADANACIOĞLU, H. (2011). "The Futures Market in Agricultural Products and an Evaluation of the Attitude of Farmers: A Case Study of Cotton Producers in Aydin Province in Turkey”. New Medit, No. 2011-II, pp. 58-64

AGRA, (2009). AGRA Stories from the.http://www.agra-alliance.org/content/ story/ detail/1002

ANDRADE, M. (2011). Correspondent Banking to Increase Outreach to Smallholder Farmers: The HDFC Bank Experience. Hyderabad.

BAYANER, A. And O. BOR. (2006). "Do the Policies Always Have the Same Consequences? The Impact of Direct Income Support on Wheat Production: The Case of Turkey”. New Medit, No. 2006-I, pp. $15-20$

BECKMAN, Jayson, BORCHERS Allison, and Carol A. JONES. Agriculture's Supply and Demand for Energy and Energy Products, EIB-112, U.S. Department of Agriculture, Economic Research Service, May 2013.

BINSWANGER, Hans P., SHAHIDUR R. Khandker, and Mark R. ROSENZWEIG. (1993). "How Infrastructure and Financial Institutions Affect Agricultural Output and Investment in India." Journal of Development Economics 41: 337-66

BURRELL, A. and M. KURZWEIL. (2007). "Distortions to Agricultural Distortions in Turkey", Working Paper 10, Wageningen University and World Bank.

BUSSE S., BRUMMER B. and IHLE R. (2010) The Pattern of Integration between Fossil Fuel and Vegetable Oil Markets: The Case of Biodiesel in Germany. Paper presented at the Agricultural \& Applied Economics Association 2010 AAEA,CAES, \& WAEA Joint Annual Meeting, Denver, Colorado, July 25-27, 2010.

BYERLEE, D. de Janvry, A. and E. SADOULET. (2009), "Agriculture for Development: Toward a New Paradigm”, Annual Review of Resource Economics, Vol. 1: 15-35, October 2009.

CBRT, (2014). Inflation Report 2014-III. Ankara.

CHARLES, H. Gibson and Patricia A. FRISHKOFF. (1983). Financial Statement Analysis. 2'nd Edition. Kent Publishing Company. Boston, Massachusetts.

CERVANTES-GODOY, D. and J. BROOKS. (2008). "Smallholder Adjustment in Middle-Income Countries: Issues and Policy Responses”, OECD Food, Agriculture and Fisheries Working Papers, No. 12, OECD, Paris.

CERVANTES-GODOY, D. and J. DEWBRE. (2010). "Economic Importance of Agriculture for Poverty Reduction", OECD Food, Agriculture and Fisheries Working Papers, No. 23, OECD Publishing.

CGAP, (2010). "How Is the Financial Crisis Impacting Our World and Our Work?" CGAP spreadsheet, Washington, DC.

CHEN, S. and M. RAVALLION. (2009). “The Impact of the Global Financial Crisis on the World's Poorest.” http://tinyurl. com/ccagl8.

CHRISTEN, R. and D. PEARCE. (2005): Managing Risk and Designing Products for Agricultural Micro Finance - Features of an Emerging Model. CGAP Occasional Paper 11

ÇAKMAK, M. (2006). "Sustainable Agricultural and Rural Development in Turkey“, ECO-IDB-FAO-MOJA Workshop on Agricultural Sustainable Development. Tehran.

DELLAL, Đ., MCCARL, B.A., and T. BUTT. (2011). The Economic Assessment of Climate Change on 
Turkish Agriculture, Journal of Environmental Protection and Ecology, Vol:12, No:1, 376-385

ERDEM, E., NAZLIOĞLU, Ş. (2008). “Tarımsal Destekleme Politikalarının Gelir Dağılımı Üzerindeki Etkileri: Türk Tarım Sektörü Örneği”.Türkiye İstatistik Kurumu 16. İstatistik Araştırma Sempozyumu, Sosyo-Ekonomik Gelişme ve İstatistik, 10 - 11 Mayıs 2007, Ankara-Türkiye. (Bildiriler Kitabında Basıldı: Mart 2008, ss. 118-132).

FAO and GTZ, (1998). Agricultural Finance Revisited: Why? FAO/GTZ AFR Series No 1, FAO: Rome.

FAO, (2004). Agricultural Finance Revisited No. 7 Financing Agricultural Term Investments. Available at: http://www.fao.org/docrep/008/y5565e/y5565e00.htm\#Contents

FAO and OECD, (2009). Agricultural Outlook 2009-2018. FAO: Rome.

FAO, (2013). World Food and Agriculture. The 2013 FAO Statistical Yearbook. Food and Agriculture Organization of the United Nations. Rome, 2013

GELLINGS, C., and K.E. PARMENTER. 2004. "Energy Efficiency in Fertilizer Production and Use," in Efficient Use and Conservation of Energy, C.W. Gellings and K. Blok (eds.).

GIRARDI, D. (2013). Financialization of food - The determinants of the time-varying relation between agricultural prices and stock market Dynamics Online at http://mpra.ub.uni-muenchen.de/56650/

HAMILTON, J. 2009. “Causes and Consequences of the Oil Shock of 2007-08.” Brookings Papers on Economic Activity, 1: 215-261.

HOFF, Karla and Joseph E. STIGLITZ. (1990). "Introduction: Imperfect Information and Rural Credit Markets-Puzzles and Policy Perspectives." World Bank Economic Review 4 (3): 235-50.

HOLLINGER, F. (2011). Agricultural Finance -Trends, Issues and Challenges. Deutsche Gesellschaft für Internationale Zusammenarbeit (GIZ) GmbH. Bonn. Germany.

IFAD, (International Fund for Agricultural Development). (2009). "The Future of World Food Security: Investing in Smallholder Agriculture-An International Priority." Rome: IFAD.

IFC, (2012). “Innovative Agricultural SME Finance Models”. Washington. USA

IFC, (2014). "Agriculture Finance“. Available at: http://www.ifc.org/wps/wcm/connect/Industry_ EXT_Content/ IFC_External_Corporate_Site/Industries/Financial+Markets/Retail+Finance/ Agriculture+Finance/

IFPRI/Terrafrica/GTZ (International Food Policy Research Institute/Terrafrica/ Deutsche Gesellschaft für Technische Zusammenarbeit), (2009). The World Food Crisis, Land Degradation, and Sustainable Land Management: Linkages, Opportunities, and Constraints. Washington, DC: IFPRI/Terrafrica/ GTZ.

IRZ, X., LIN, L., THIRTLE, C. and WIGGINS, S. (2001). "Agricultural Growth and Poverty Alleviation." Development Policy Review 19 (4): 449-466.

KLEIN, B., MEYER, R., HANNIG, A., BURNETT, J. and M. FIEBIG, (1999). Better Practice in Agricultural Lending. FAO/GTZ Series No 3, FAO: Rome.

LEVINE, Ross. (1997). “Financial Development and Economic Growth: Views and Agenda." Journal of Economic Literature 35 (2): 688-726.

LIPTON, M. (1977). Why poor people stay poor: urban bias in world development. Cambridge: Harvard University Press.

McCARL, B.A. and İ. DELLAL (2010). “The Economic Impact of Drought on Agri.., 2nd Int Conf on Drought Management, Istanbul

McDONALD, P. Benjamin Jr., PIPREK, Gerda L., and YARON, Jacob. (1997). Rural Finance: Issues, Design, and Best Practices. Washington, DC: World Bank. 
MEYER, R. and G. NAGARAJAN. (2005). Rural Finance. Recent Advances and Emerging Lessons, Debates and Opportunities. Reformatted version of Working Paper No. (AEDE-WP-0041-05), Department of Agriculture, Environmental, and Development Economics, The Ohio State University, Columbus, Ohio.

MIHCI, H. And Ş. MOLLAVELİĞLU. (2011). "An Assessment of Sustainable Agriculture in the OECD

Countries with Special Reference to Turkey". New Medit, Vol 2, n. 1, (June 2011), pp. 4-17

MILLER, C. and l. JONES. ( 2010). Agricultural Value Chain Finance-Tools and Lessons. Published by Food and Agriculture Organization of the United Nations and Practical Action Publishing.

OSKAM A., BURREL, A., TEMEL, T., VAN BERKUM, S., LONGWORTH, N., and VILCHEZ, I. M. (2004). Turkey in the European Union: Consequences for Agriculture, Food, Rural Areas and Structural Policy. Wageningen University, Netherland.

RILEY, J. M. and ANDERSON, J.D., 2009. Producer Perceptions of Corn, Soybean and Cotton Price Risk, Southern Agricultural Economics Association Annual Meeting, Atlanta, Georgia, January 31February 3, 20p.

SCHNITKEY, G. 2011. "Relationship between Anhydrous Ammonia and Natural Gas Prices." FEFO-18, Department of Agricultural and Consumer Economics, University of Illinois.

SWINNEN, J. F. M. and H. R. GOW. (1997). Policy Research Group Working Paper No:6 “ Agricultural Credit Problems and Policies during the Transition to a Market Economy in Central and Eastern Europe". Katholieke Universiteit Leuven, Belgium.

TANRIVERMİş, H. and A. BAYANER. (2006). "Members' Perception and the Role of Agricultural Credit Cooperatives in Agricultural Finance in Turkey". New Medit, Vol 5, n. 3, (September 2006), pp. 23-28.

TIMMER, P. (1988). “The Agriculture Transformation”, Handbook of Development Economics, Vol. 1,Elsevier Science Publishers B.V.

TOKTAŞ, Y., SEVİNÇ, H., and Eda BOZKURT, (2013). 'The evaluation of Development Agencies: Turkey Case. Annales Universitatis Apulensis Series Oeconomica, Vol 15(2), 2013. pp. 670-681

UNCTAD (2011). 'Financialization of Commodity Price Formation', UN Publication, UNCTAD/ GDS/2011/1

UN-DESA, (2008). “Don't Forget the Food Crisis: New Policy Directions Needed.” Policy Brief 8, October, 2008. Available at: http://www.un.org/esa/ policy/policybriefs/policybrief8.pdf.

UNEP, (2011). "Agriculture-Investing in Natural Capital. Towards a Green Economy" Available at: www. unep.org/

USAID, (2010). "Warehouse Receipts: Financing Agricultural Producers" Technical Note, No.5. Available at: http://pdf.usaid.gov/pdf_docs/PNACQ697.pdf

WORLD BANK, (2003). "Rural Financial Services: Implementing the Bank's Strategy to Reach the Rural Poor.” Report No. 26030, World Bank, Washington DC.

WORLD BANK, (2006). Meeting Development Challenges: Renewed Approaches to Rural Finance. World Bank: Washington, D.C.

WORLD BANK, (2007). World Development Report 2008: Agriculture for Development. World Bank, Washington, DC.

WORLD BANK, (2008). “The Growth Report: Strategies for Sustained Growth and Inclusive Development”, Commission on Growth and Development, The International Bank for Reconstruction and Development/The World Bank. 
WORLD BANK, (2009). "Protecting Progress: The Challenge Facing Low-Income Countries in the Global Recession.” Background paper prepared by World Bank Group staff for the G-20 Leaders' Meeting, Pittsburgh, PA, September 24-25.

WORLD BANK, (2011). Joint Discussion Payper 2011: Subsidies As An Instrument In Agriculture Finance: A Review World Bank, Washington, DC.

WORLD BANK, (2014). Turkey Overview. Available at: http://www.worldbank.org/en/ country/ turkey/ overview\#1 
